\title{
THE AGE-OLD COSSACK FEAST OF THE PROTECTING VEIL: A CONTEMPORARY INTERPRETATION OF A TRADITIONAL CALENDAR DATE
}

\author{
Nina Vlaskina
}

\begin{abstract}
The article analyses the history and content of the modern Cossack celebration of the Feast of the Protecting Veil (Rus. Pokrov) of the Mother of God. The members of the Cossack movement call it the main Cossack national holiday. The article discusses the reasons and historical basis for such a characterisation of the celebration, and systematises its components that have emerged during different historical stages, using a wide variety of sources: ethnographic research articles, periodicals, Internet blogs and forums, as well as unpublished archive materials. The contemporary Cossack festival of the Protecting Veil combines the traits of the Host holidays and civil funerals, and pursues primarily etiquette objectives: particularly the confirmation of the succession of the status upwards from the prerevolutionary Cossacks to the modern ones, updating cultural values in a new environment. To achieve these goals, the organisers use universal components that have no time constraint and actively appeal to different layers of historical memory.
\end{abstract}

Keywords: calendar rites, contemporary feasts, Cossacks, identity, Russia, the Protecting Veil of the Mother of God

In modern Russia one of the issues under discussion is that of identity (civil, religious and ethnic). There are several reasons for it, including change of boundaries and composition of the federal administrative units in 1991, the return from state atheism to Orthodoxy, and worldwide trends of globalisation. For such a population group of Russia as the Cossacks, the question of identity turns out particularly complex.

In the early stage (15th-17th centuries) the Don Cossack community was made up of different ethnic groups (with a Russian majority), who settled in the southern outlying districts of the Russian state. The economic-cultural type of community in this period can be defined as 'war and hunting'. There were certain preconditions for a new ethnic group to be formed, with such features of spiritual culture as the rejection of cultural values of agricultural 
Slavs; the transformation of life-cycle rituals; the emergence of the horse cult and appearance of the original initial rite; the development of special laws; the deployment of military and democratic forms of community life organisation (selectivity and inter-changeability of leaders, the circle as a form of participation of all community members in the decision making process, etc.) (Protsenko 1998: 82).

As a result of Peter the Great's reforms, at the beginning of the 18th century, the process of ethnogenesis in the Don region was interrupted and the Russian government consistently pursued a policy of conversion of the Don Cossacks into a military estate of the Russian Empire.

Soon after the October Revolution of 1917, all estates (the nobles, the merchants, the petty bourgeoisie, the Cossacks, and others) were cancelled. Accordingly, the Cossacks underwent another change of status. After the collapse of the Soviet Union, the Cossacks have reaffirmed their rights and begun to discuss the question of identity: whether they are an estate or a nation. To strengthen their position both in the political arena and in the public consciousness, they invent some practices and along with it attribute new meanings to existing cultural forms. It is well known that many local traditions extensively use holidays in this function.

In this article, I have selected for the analysis the history and content of the modern Cossack celebration of the Feast of the Protecting Veil of the Mother of God. The members of the Cossack movement call it the main Cossack national holiday. The following step will be to discuss the reasons and historical basis for such a characterisation of the celebration, and to systematise its components that have emerged during different historical stages.

Below I will analyse the history of the traditional Cossack celebration of the festival, the differences between the content of the calendrical rituals and popular beliefs of the Cossacks and those of other groups of Russians, Cossack civil funerals as an official event, and festivals of the Cossack hosts (armies). This allows me to describe more precisely the content and axiological dominants of the contemporary Feast of the Protecting Veil.

In order to conduct a diachronic analysis, it was necessary to use several groups of sources: descriptions of the Cossack holidays in the 19th century, published in the periodicals and in the ethnographic research by M. Kharuzin (1885), Cossack emigrant journals and books from the mid-20th century, Internet blogs and forums, and also field materials of ethnolinguistic and dialect expeditions of the Southern Federal University (previously known as Rostov State University) and the Institute of Social-Economic Research and Humanities of the Southern Scientific Centre of the Russian Academy of Sciences, both separate and joint. 


\section{THE HISTORY OF THE CELEBRATION OF THE PROTECTING VEIL}

The Day of the Protecting Veil of the Mother of God (October 1(OS) / 14(NS)) is an Orthodox holiday that was established in memory of the vision of the Mother of God to St. Andrew the Fool-for-Christ in Blachernae church in Constantinople. The Mother of God stretched out her protecting veil over the besieged city and the people (Hagiography 2004: 5-6). The holiday was established on the territory of the Kiev province, and therefore remained virtually unknown to other churches, except Russian, or appeared there as a result of Russian influence. The intercession of the Blessed Virgin Mary, her patronage and shrouding as the basic ideas of the holiday, were grasped in the folk traditions of the Eastern Slavs (Agapkina 2009: 27).

The Feast of the Protecting Veil falls on the middle of autumn, and, owing to this, in the Russian folk calendar it marks the transition to winter and also the beginning of the wedding period, which was interrupted for the time of field work (ibid.).

In the Don region the folk motifs of the holiday associated with the end of the agricultural year are not as popular as in the central and northern regions of Russia, due to the natural conditions, namely the later onset of winter. In Central Russia the last pasturing of cattle was timed for the Feast of the Protecting Veil, whereas in the south of Russia cattle could be grassed until December. Russians in the regions further to the north believed that it was time for the ground to be covered with snow, whereas Cossacks regarded the fall of snow on this day as a sign of a severe ${ }^{1}$ or 'rotten' (rainy) ${ }^{2}$ winter. Isolated instances of preparation for the winter season (storing up hay and coal, washing and puttying windows) can be found in the materials from the Russian-Ukrainian borderlands, ${ }^{3}$ and a practice of planting garlic on this day was once recorded in the central part of the Don area. ${ }^{4}$ It should be noted that in the Don region agricultural rites in general have been preserved in a much reduced form (Gnutova \& Protsenko 2004: 48), because of the military service as a major form of the Don Cossack activity, as well as the migratory type of culture.

Marital motifs constitute the core of the Don Cossack beliefs about the Feast of the Protecting Veil. This day was the boundary around which matchmaking rites or weddings were concentrated. The proverb "The Protecting Veil comes, the maid roars like a cow", describing the sorrow of a girl who failed to become engaged that year, is widespread in the Don area.

Field data do not provide us with information about any sorts of social activities timed for this date, except for the places where churches were consecrated 
in the name of the Protecting Veil of the Mother of God, and therefore this day was a patronal festival.

Besides, there were civil celebrations timed for October. On December 24, 1890, Russian Emperor Alexander III issued his Decree No. 32, establishing October 17 as a special official day for the Don Cossack Host. This day was marked in the text of the decree as the day of a miraculous escape of the regnant family, threatened by a dangerous crash of the imperial train in 1888 , and the memory of prophet Hosea. October 1 was established as an officially celebrated holiday of all Cossack hosts. Henceforth, having become a civil event, the feast had much in common with other city holidays in different Russian territories regarding special organisers and a rather detailed scenario. In 1904, Imperial Decree No. 547 (issued on October 15) moved the military celebration of the Don Host to October 5, which was the name day of Prince Alexei, the august ataman of all Cossack hosts. The holiday was returned to an earlier date in August 1917 by African Bogaevsky, who was the chairman of the All-Great Don Host Government. After the Civil War the holiday was not celebrated in Soviet Russia, and the Cossack hosts were dissolved, as mentioned above. Thus, the tradition to celebrate the Host Day in October only existed for less than 30 years of all the four hundred years of the Don Cossacks' history.

We should also note here that the Civil War period was characterised by a surge of nationalist sentiment among the Cossacks. Disintegration processes in the Cossack regions of southern Russia led to the emergence of political entities which claimed an official status. When it was necessary to strengthen the status of the Cossacks and their territorial claims, the very idea of the Host Day performed an important integrating and stabilising function.

According to an eyewitness of the festive actions, a Cossack emigrant S. Boldyrev (1949), the chronology of the Host Day in Novocherkassk in 1918 lined up as follows. First the ataman inspected the troops participating in the parade, and then they carried the Cossack regalia out, including horsetails as symbols of authority, church banners, charters of kings and emperors, which were granted to the host for the age-old service and loyalty to Russia, etc. The next element of the celebration was the service performed in the cathedral, after which the icons and church banners were taken to the square. Next, the gunfire ceremony was performed, the parade of Cossack military units was held, and a common meal ('the host's bread and salt') was organised. At dinner the army orchestra played and the army choir in blue garments sang old songs.

In the 1920s, after the defeat of the White movement, many of the Cossacks were forced to leave Russia. In exile, due to the consistent emphasis on the national specificity of the Cossacks, the Host Day acquired additional meanings. 
Researchers of the dynamics of traditional cultures demonstrate that historical events play a crucial role in constructing and reconstructing rituals and techniques (Hobsbawm 1983: 4). Irina Sedakova (2008) and Victoria Popova (2008) have presented modern Russian holidays from this point of view. Inventors of new traditions provide feasts with a mythological aura to strengthen their position in the public mind (Popova \& Shumikhina 2008).

Different texts associated with the Feast of the Protecting Veil illustrate this trend. Some Kuban sources date the Cossack origin back to ancient times and consider the Cossacks to be present at the miraculous appearance of the Mother of God in the Blachernae church. They say that "this event was engraved in the memory of Cossack ancestors for a thousand years" (The Festival of the Host 1931: 2).

In many cases, the history of the Host Day can be traced back to the mythologised event of the miraculous appearance of Our Lady before the praying Cossacks in Azov town besieged by the Turks on the Feast of the Protecting Veil in 1641. The defence, embodying the symbolic meaning of the icon and the feast, correlated with the Cossacks' function of defending the Russian boundaries. According to an emigrant's article published in 1981, since then the Feast of the Protecting Veil has become not only a church festival but also a great all-Cossack festival (Protecting Veil 2012).

The authors of the Cossack dictionary published in the United States in 1966-1970 pointed out that the public liturgy was performed near Starocherkassk, on the site of the former monastic settlement, "annually, on the first day of October, on the Feast of the Protecting Veil, as a sign of honouring their ancestors, namely the Cossacks, who were killed during combat encounters with the enemy, and as a prayer for their souls" (Skrylov \& Gubarev 1992: 111).

Indeed, prior to the $1880 \mathrm{~s}$, worship of the dead Cossacks was annually conducted on the abovementioned site. However, it was carried out not on the Feast of the Protecting Veil, but in the Pancake week (in spring) (Popov 1905: 5). A similar funeral service in similar terms took place in Stanitsa (village/rural locality) Luganskaya (Kharuzin 1885: 384). It corresponded to the traditional terms of commemoration of the faithful departed (Agapkina 2002: 44).

The fact is that the denomination of the Feast of the Protecting Veil as an all-Cossack festival has little ground. The 19th-century sources give us no evidence of celebrating the Feast of the Protecting Veil or holding funeral services on this day. Thus, emigrant materials ascribed the status of the Host Day to a wrong holiday, and they named it universal, ubiquitous and existing from time immemorial, while the civic festivals of the Hosts had quite a peculiar history and a limited time frame of existence. 
The process of the Cossack revival, which began in the 1990s, required ideological support. The emigrants' works, whose status improved, inter alia, because they had been hidden from the general reader for a long time, were used in this capacity. It is the in-exile version in which the Cossack Host Day was restored. The texts generated by the representatives of the modern Cossack community call the Feast of the Protecting Veil just an original Cossack holiday. ${ }^{5}$

At the state level, civil events timed for this day were established by including the Feast of the Protecting Veil of the Mother of God in the list of the annual cultural mass events of a regional value (in 1988), and later on (in 2001) by setting the annual Memorial Day or the Day of Cossack Glory on the last Saturday before the Feast of the Protecting Veil.

The need to increase the importance of the Host Day, just as it had happened earlier, led to the actualisation of the memories of historical events, connected with this day one way or another. It is significant that in the modern mass media no one remembers the role of Alexander III and African Bogaevsky in establishing the days of the Cossack Hosts. I see the influence of the emigrants' views in the fact that modern Cossacks identify the Host Day with the Feast of the Protecting Veil. Most often they refer to the appearance of the Virgin before the Cossacks who defended Azov against the Turkish attack in $1641 .^{6}$ Less common are other facts, such as gratitude, declared by Field Marshal Kutuzov to Cossacks in $1812 .^{7}$

The combining of several festive occasions probably also serves the purpose of improving the status of the holiday. It becomes possible due to the parallel existence of different calendars (the civilian - both on the state and regional level - and the ecclesiastical one). The Feast of the Protecting Veil can be merged with the Farmers' Day, the Day of the Recruit, and the Day of the Village. It should be noted that in many communities the Day of the Village replaced the Patron Saint's Day in the Soviet era, and many churches of the Don region were consecrated to the Protecting Veil of the Mother of God.

In 2012, the activities of the Cossack communities were timed for the Feast of the Protecting Veil and for the 200th anniversary of the victorious participation of the Don Cossacks in the Patriotic War of $1812 .^{8}$

\section{THE CONTENT OF THE MODERN COSSACK FEAST OF THE PROTECTING VEIL}

Today we are witnessing the transformation of the calendar date perception. The Feast of the Protecting Veil enhances its status due to the fact that the Host Day is considered to be timed for it, and after that a change of emphasis 
takes place, and the Feast of the Protecting Veil turns from the Cossack Host Day into a primordial Cossack feast.

Below I will examine the content of the modern Cossack Feast of the Protecting Veil.

The first component is a festive service in the church or a memorial service for the dead Cossacks in the field, related to the historical events in the life of the Cossack Host. The content of this component has not undergone any significant changes, as it is probably highly regulated. However, its perception has changed. As already mentioned, the Protecting Veil memorial service on the site of the former monastic settlement was declared to be much older than it really was. The fact that neither field records nor mass media materials give us evidence of a local ritual practice in the Don region, connected to the icon of the Protecting Veil, may testify to the idea that rapt attention to this feast as very important for the Cossacks has no deep roots and has appeared only recently.

The second component is the parade, exercises, and demonstration of military skills (horse racing, fancy riding, slashing). According to ethnographic sources, these were characteristic elements of Cossack holidays in the 19th century (Timoshchenkov 1873). In addition to the manifestations of daring and the integrating function, these exercises also had a pragmatic meaning, namely, the training of young Cossacks for military service, as all these skills were needed in combat. As a part of today's celebrations timed for the Feast of the Protecting Veil, they are preserved in a form close to the old one, or can be transformed into a competition of reenactors.

Under the name 'the Cossack Saviour', or 'national games of the Cossacks' (Shermitsii) they have moved into the category of ethnic sports (one of the founders of the Shermitsii is the All-Russian Federation of Ancestral Fun and Russian Ethnosport). The announced aim of these actions is the preservation of historical roots, values and traditions of the Cossacks, but the organisers have not commented on the change of the historical context and lack of demand for these kinds of skills, and thus the strengthening of the entertainment and gaming dominance of the event.

Public meals, being known to many people as a mandatory attribute of a holiday tradition that has constitutive and consolidating functions, are supplemented or replaced by modern forms of leisure: master classes (how to cook Cossack fish soup), ${ }^{9}$ tastings (field kitchen, so-called soldier's porridge),${ }^{10}$ which leads to a change in the function of this element. Having soldier's porridge as a ritual meal on a number of occasions shows a trend towards the universalisation of ritual forms. Not so long ago, tasting soldier's porridge became an integral component of celebrating the Day of Victory in the Great Patriotic War of 1941-1945, in which it has primarily the commemorative function. 
The mechanical transfer of ritual meals into a series of activities timed for the Feast of the Protecting Veil erodes the meaning of the holiday, partly because in pre-revolutionary Russia, whose festive regulations appeal to those reviving the Host Day, soldiers and Cossacks were countered both on the official level (regular and irregular troops) and as a stereotype (ordinary men - the Cossacks).

Finally, the organisers include the universal forms in the list of festive activities which were the most widespread in the Soviet period: an award presentation (prominent people in agriculture, the best Cossack squad), a concert given by folk groups, games and competitions (including the best performance of Cossack cadet songs, and the best camping cooking of Cossack meals).

An interesting fact is that the name and semantics of the festival can be used with respect to the activities carried out under other terms. For example, in 2011, the so-called Cossack national games timed for the Feast of the Protecting Veil were held on the Day of the Nativity of the Mother of God and, therefore, were simultaneously linked by the organisers to the two traditional calendar dates. Apparently, this fact was to testify to the high level of religiosity of the Cossacks. In April of the same year, the International Festival of Cossack folklore groups under the heading The Protecting Veil on the Don (Festival 2011) was held in the Millerovsky district of the Rostov region (where most of the population are non-Cossack). The correlation between festivities and the agrarian or the professional year cycle has disappeared. By the words of Jeremy Boissevain, "hence, when they [the feasts] are celebrated is now a matter of convenience" (Boissevain 2013: 206).

Thus we see that the content of the so-called 'Cossack' feast involves some elements typical of many European festive scenarios. Church services or masses and common meals are an integral part of patronal feasts. Sport activities and various competitions have also often been connected with local festivals (especially recently) (Fournier 2007).

Elements of different historical layers are mixed and transformed in the analysed celebration to achieve the central aim of demonstrating the Cossack specificity. The very idea to label this feast as a Cossack one could be interpreted as a way to accentuate their presence in the ritual year. Different objects and practices gain the 'Cossack' attributes throughout all festive activities. Men often attend a church service on the Feast of the Protecting Veil, wearing the Cossack uniform. The re-enactment named Shermitsii is presented as a revitalised old Cossack tradition. In fact, it is a kind of restored or resurrected practice (Boissevain 2013: 202), to put it more precisely. Old Cossack training exercises were introduced and organised in a form of periodical games by educated men elaborating the issues of Russian traditional sports. They use new materials (e.g. plastic bottles with water instead of streams of water or thick sticks) and 
modern sportswear. In addition to various forms of competition, organisers include different kinds of exams in the programme of the Shermitsii to test the knowledge of the Cossack rituals and beliefs. As was mentioned above, the food cooked for the feast may be characterised as typically Cossack.

The practice of the Cossack celebration of the Feast of the Protecting Veil represents the way that an ethnic or social group can manifest its interests within the framework of the ritual year. The modern content of the analysed feast absorbs several symbolic meanings and includes elements from different historical layers:

1. An Orthodox holiday and a Slavic traditional feast marking the symbolic border between autumn and winter seasons;

2. A practice of annual worship of the Cossacks killed in action;

3. Officially celebrated October feasts of all Cossack hosts and of the Don Cossack Host in the pre-revolutionary period.

In the 20th century the Cossack emigrants provided the Feast of the Protecting Veil with a long mythologised history, and throughout several decades the members of the modern Cossack movement have adopted these ideas, and now they widely celebrate 'the age-old Cossack Feast of the Protecting Veil'. ${ }^{11}$ So, the Cossack activists turned one of the Slavic traditional feasts into a vehicle for strengthening their position in the political and local scene. The motive for choosing this holiday to promote Cossack interests was the notion of defence, which is one of the meanings of the icon and also the main function ascribed to the Cossacks as a former estate of the Russian Empire. The objective of the festivity organisers is the confirmation of the succession of the status from the prerevolutionary Cossacks to the modern ones, as well as updating of cultural values in a new environment. To achieve these goals, they exploit universal components that have no time constraint, and actively appeal to different layers of historical memory.

\section{ACKNOWLEDGEMENTS}

This article is part of a collective basic research project of the Institute of SocialEconomic Research and Humanities SSC RAS (2013-2015), titled Istoricheskie formy $i$ sovremennye sposoby funktsionirovaniia sotsiokul'turnykh institutov na Iuge Rossii (Historical Forms and Modern Ways of Functioning of the SocioCultural Communities in the South of Russia). 


\section{NOTES}

1 Folder 23, 2000, Zimovnikovsky district of the Rostov Region; folder 27, 1999, Konstantinovsky district of the Rostov Region; folder 77, 2003, Tarasovsky district of the Rostov Region. Manuscript Archive, Chair of General and Comparative Linguistics, Southern Federal University.

2 Folder 72, 2003, Azovsky district of the Rostov Region. Manuscript Archive, Chair of General and Comparative Linguistics, Southern Federal University.

${ }^{3}$ Folder 77, 2003, Tarasovsky district of the Rostov Region. Manuscript Archive, Chair of General and Comparative Linguistics, Southern Federal University.

4 Folder 98, 2009, Morozovsky district of the Rostov Region. Manuscript Archive, Chair of General and Comparative Linguistics, Southern Federal University.

5 Rossiiskomu kazachestvu posviashchaetsia. Informatsionnyi portal: Ot kazakov TsKV vsem brat'iam-kazakam: s Prazdnikom, Braty-Kazaki. [Dedicated to the Russian Cossacks. Informational Portal: From the Cossacks of the Central Cossack Host to All Brothers-Cossacks: Congratulations, Brothers-Cossacks.] October 8, 2013. Available at http://kazachestvu.ru/kazaki/1109, last accessed on January 26, 2015.

6 Donskaia Zimovaia stanitsa: Obshchevoiskovoi kazachii prazdnik Pokrova Presviatoi Bogoroditsy. [Don Zimovaya Stanitsa: The Cossack Feast of All the Hosts of the Protecting Veil of the Mother of God.] October 4, 2012. Available at http://www. zimovaya.ru/novosti/obschevoyskovoy-kazachiy-prazdnik-pokrova-presvyatoybogoroditsy-3.html, last accessed on January 26, 2015; Vol'naia stanitsa: Otchego prazdnik Pokrova Bozhiei Materi tak berezhno chtitsia kazakami? [Free Stanitsa: Why is the Feast of the Protecting Veil of the Mother of God Honoured by Cossacks with Such Care?] Not dated. Available at http://fstanitsa.ru/category/menyu/vera/otchegoprazdnik-pokrova-bozhiei-materi-tak-berezhno-chtitsya-kazakami, last accessed on January 26, 2015; etc.

7 ITAR-TASS: Uchastniki konnogo pokhoda Moskva - Parizh otmetili glavnyi kazachii prazdnik - den' Pokrova Presviatoi Bogoroditsy. [The Members of the Horse March Moscow-Paris Celebrated the Main Cossack Feast - the Day of the Protecting Veil of the Mother of God.] October 14, 2012. Available at http://www.prazdnikmedia.ru/ archive/news/article/126859, last accessed on January 26, 2015.

8 Informatsionnyi portal Konstantinovsk.ru: Shermitsii v Pukhliakovke. [Informational Portal: Shermitsii in Pukhliakovka.] September 21, 2012. Available at http:// konstantinovsk.ru/news/21-09-2012/shermitsii-v-pukhlyakovke, last accessed on January 27, 2015.

9 Kazachii Don: Kul'turno-istoricheskii turistskii kompleks. Prazdnik Pokrova Presviatoi Bogoroditsy "Kazachii Don". [The Cossack Don: Cultural-Historical Tourist Complex. The Feast of the Protecting Veil of the Mother of God "The Cossack Don"]. October 14, 2012. Available at http://казачийдон.pp//blog/reports/prazdnik_pokrova_presvyatoy_ bogoroditsy_kazachiy_don/, last accessed on January 27, 2015. 
${ }^{10}$ KAFANEWS. Krym: novosti Feodosii: Kazaki Feodosii nakormili kuleshom. [KAFANEWS. Crimea: The News of Feodosia: The Cossacks of Feodosia Fed People with Kulesh]. October 14, 2011. Available at http://kafanews.com/novosti/35015/kazakifeodosii-nakormili-kuleshom_2011-10-14, last accessed on January 27, 2015.

${ }^{11}$ Ot kazakov TsKV vsem brat'iam-kazakam: s Prazdnikom, Braty-Kazaki. [From the Cossacks of the Central Cossack Host to All the Brothers-Cossacks: Happy Holidays, Brothers-Cossacks.] October 8, 2010. Available at http://kazachestvu.ru/kazaki/1109, last accessed on January 27, 2015.

\section{REFERENCES}

Agapkina 2002 = Agapkina, Tat'iana. Mifopoeticheskie osnovy slavianskogo narodnogo kalendaria: Vesenne-letnii tsikl. [The Mythopoetical Basis of the Slavic Folk Calendar: The Spring/Summer Cycle.] Moskva: Indrik.

Agapkina 2009 = Agapkina, Tat'iana. Pokrov. [Feast of the Protecting Veil.] In: N. Tolstoi (ed.) Slavianskie drevnosti. Etnolingvisticheskii slovar'. T. 4: Pereprava cherez vodu - Sito. Moskva: Institut slavianovedeniia RAN, pp. 127-128.

Boissevain, Jeremy 2013. Factions, Friends and Feasts: Anthropological Perspectives on the Mediterranean. New York \& Oxford: Berghahn Books.

Boldyrev 1949 = Boldyrev, Sergei. Voiskovoi prazdnik. Vospominanie nedavnego proshlogo, posviashchaetsia svetloi pamiati donskogo atamana P. N. Krasnova. [The Festival of the Host: The Recollection of the Near Past, Dedicated to the Blessed Memory of the Don Ataman P. N. Krasnov.] Obshchekazachii zhurnal, No. 9, pp. 2-6. Available at http://elan-kazak.ru/sites/default/files/IMAGES/ ARHIV/Periodika/okzh/OKG-9-1949.pdf, last accessed on January 27, 2015.

Festival 2011 = Festival' "Pokrova na Donu" na Millerovskoi zemle. [Festival "The Protecting Veil on the Don" on the Millerovsky Land.] Newspaper Nash krai, April 9, p. 7.

Fournier, Laurent Sébastien 2007. Traditional Games and the Ritual Year in Provence (France): From Ludodiversity to Cultural Heritage. The Ritual Year and Ritual Diversity: Proceedings of the Second International Conference of the SIEF Working Group on the Ritual Year. Gothenburg, June 7-11, 2006. Göteborg: Institutet För Språk och Folkminnen Dialekt-, Ortnamns- och Folkminnesarkivet i Göteborg, pp. 183-190.

Gnutova \& Protsenko 2004 = Gnutova, Liudmila \& Protsenko, Boris. K izucheniiu donskoi kalendarnoi obriadnosti: prazdnovanie Novogo goda. [On the Issue of the Don Calendar Rites: The New Year Celebration.] Traditsionnaia kul'tura, No. 4, pp. 48-53.

Hagiography 2004 = Zhitiia sviatykh sviatitelia Dimitriia Rostovskogo. Tom 2: Oktiabr'. [Hagiography by St. Dimitry Rostovsky. Volume 2: October.] Kiev: Phoenix.

Hobsbawm, Eric 1983. Introduction: Inventing Traditions. In: Eric Hobsbawm \& Terence Ranger (eds.) The Invention of Tradition. Cambridge University Press, pp. 1-14. 
Kharuzin 1885 = Kharuzin, Mikhail. Svedeniia o kazatskikh obshchinakh na Donu. Materialy dlia obychnogo prava, sobrannye Mikhailom Kharuzinym. [Data on the Don Cossack Communities: Materials for the Common Law Collected by Mikhail Kharuzin.] Moskva: Tipografiia M. P. Shchepkina. Available at http://www. history-fiction.ru/books/all_1/user_4_1/region_110_10/section_1_1/sort_2_1_2/ book_230/, last accessed on January 27, 2015.

Popova \& Shumikhina 2008 = Popova, Viktoriia \& Shumikhina, Liudmila. Transformatsiia form prazdnichnoi kul'tury: igrovoi aspekt. [The Transformation of the Festive Activity Forms: The Gaming Aspect.] Izvestiia Ural'skogo gosudarstvennogo universiteta, No. 55, pp. 25-33.

Popov $1905=$ Popov, Khariton. Istoricheskaia panikhida na Monastyrskom urochishche. [Historical Service for the Dead in the Former Monastic Settlement.] In: Pamiatnaia knizhka Oblasti Voiska Donskogo na 1905 g. Novocherkassk: Oblastnaia v. D. tipografiia. Part 3, pp. 3-5.

Protecting Veil 2012 = Pokrov Bogoroditsy - prazdnik kazachestva. [The Feast of the Protecting Veil of the Mother of God as a Holiday of the Cossacks.] In: Konstantin Khokhul'nikov (comp.) Kazaki Rossii! Sbornik statei, ocherkov $i$ stikhov avtorov kazach'ego zarubezh'ia. Rostov-na-Donu: Donskoi Izdatel'skii Dom, pp. 361-363.

Protsenko 1998 = Protsenko, Boris. Etnolingvisticheskaia kontseptsiia proiskhozhdeniia i kharaktera dukhovnoi kul'tury donskikh kazakov. [The Ethnolinguistic Conception of the Origin and Nature of the Don Cossacks' Spiritual Culture.] Nauka o fol'klore segodnia: mezhdistsiplinarnye vzaimodeistviia. Tezisy mezhdunarodnoi nauchnoi konferentsii k 70-letnemu iubileiu Fedora Martynovicha Selivanova (Moskva, 29-31 oktiabria 1997 g.). Moskva: Dialog MGU, pp. 80-82.

Sedakova, Irina A. 2008. Inventing the Ritual Year in Modern Russia. The Ritual Year and History: Proceedings of the Third International Conference of the SIEF Working Group on the Ritual Year. Strážnice: Institute of Folk Culture, pp. 51-58.

Skrylov \& Gubarev 1992 = Skrylov, Aleksei \& Gubarev, Vitalii (eds.) Kazachii slovar'spravochnik. Reprintnoe vosproizvedenie izdaniia 1966-1970 gg. [The Cossack Reference Book. Reprint of the 1966-1970 Edition.] Tom 1. Moskva: TO “Sozidanie”.

The Festival of the Host 1931 = Voiskovoi prazdnik. [The Festival of the Host.] Kubanskoe kazachestvo: Istoriko-literaturnyi i illiustrirovannyi zhurnal. No. 1, pp. 1-4. Available at http://archive.org/stream/kubanskoekazache00obsh\#page/ n6/mode/1up, last accessed on January 27, 2015.

Timoshchenkov 1873 = Timoshchenkov, Ivan. Iz Kazanskoi stanitsy: Obuchenie maloletkov voennomu delu. [From Kazanskaya Stanitsa: Training of Young Cossacks for Military Service.] Donskie oblastnye vedomosti, No. 3, January 16, pp. 2-3. 